\section{LESSONS FROM THE BANKING CRISIS: A RETURN TO NARROW BANKING}

\author{
Paul De Graume*
}

\section{The basics of banking}

In order to draw lessons from the banking crisis, it is useful to start from the basics of banking. ${ }^{1}$ Banks are in the business of borrowing short and lending long. In doing so they provide an essential service to the rest of us, i.e., they create credit that allows the real economy to grow and expand.

This credit creation service, however, is based on an inherent fragility of the banking system. If depositors are gripped by a collective movement of distrust and decide to withdraw their deposits at the same time, banks will be unable to satisfy these withdrawals as their assets are illiquid. A liquidity crisis erupts.

In normal times, when people have confidence in the banks, these crises do not occur. But confidence can quickly disappear, for example, when one or more banks experience a solvency problem due to non-performing loans. Then bank runs are possible. A liquidity crisis erupts that can bring down sound banks also. The latter become innocent bystanders that are hit in the same way as the insolvent banks by the collective movement of distrust.

The problem does not end here. A devilish interaction between liquidity crisis and solvency crisis is set in motion. Sound banks that are hit by deposit withdrawals have to sell assets to confront these withdrawals. The ensuing fire sales lead to declines in asset prices, reducing the value of banks' assets. This in turn erodes the equity base of the banks and leads to

\footnotetext{
* University of Leuven and CESifo.

${ }^{1}$ A very useful book is Goodhart and Illing (2002).
}

a solvency problem. The cycle can start again: the solvency problem of these banks ignites a new liquidity crisis and so on.

The last great banking crisis occurred in the 1930s. Its effects were devastating for the real economy. After that crisis the banking system was fundamentally reformed. These reforms were intended to make such a banking crisis impossible. The reforms had three essential ingredients. First, the central bank took on the responsibility of lender of last resort. Second deposit insurance mechanisms were instituted. These two reforms were aimed at eliminating collective movements of panic. A third reform was intended to prevent commercial banks from taking on too many risks. In the US this took the form of the GlassSteagall Act, which, introduced in 1933, separated commercial banking from investment banking.

Most economists thought that these reforms would be sufficient to produce a less fragile banking system and to prevent large scale banking crises. It was not to be. Why? In order to answer this question it is useful to first discuss "moral hazard".

The insurance provided by central banks and governments in the form of lender of last resort and deposit insurance gives bankers strong incentives to take more risks. To counter this, authorities have to supervise and regulate, much like any private insurer who wants to avoid moral hazard will do.

And that's what the monetary authorities did during most of the post-war period. They subjected banks to tight regulation aimed at preventing them from taking on too much risk. But then something remarkable happened.

\section{The efficient market paradigm}

From the 1970s on, economists were all gripped by the intellectual attraction of the efficient market paradigm. This paradigm, which originated in academia, became hugely popular. also outside academia. Its main ingredients are the following.

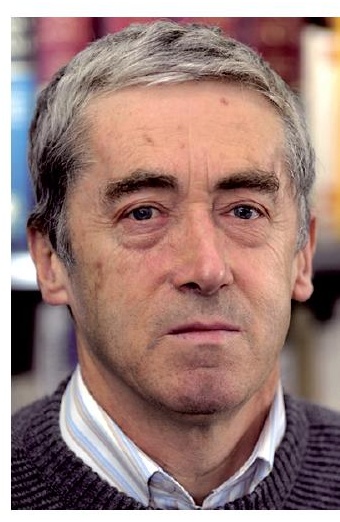


First, financial markets efficiently allocate savings towards the most promising investment projects, thereby maximizing welfare. Second, asset prices reflect underlying fundamentals. As a result, bubbles cannot occur, and neither can crashes. The third ingredient of the efficient market paradigm is the capacity of markets for self-regulation. The proponents of this paradigm told us that financial markets can regulate themselves perfectly well and that regulation by governments or central banks is unnecessary and even harmful (Greenspan 2007).

The efficient markets paradigm was extremely influential. It was also used by bankers to lobby for deregulation. If markets work so beautifully, there was no need for regulation anymore. And bankers achieved their objective. They were progressively deregulated in the US and in Europe. The culmination was the repeal of the Glass-Steagall act in 1999 by the Clinton administration. This allowed commercial banks to take on all the activities investment banks had been taking, e.g., the underwriting and holding of securities; the development of new and risky assets like derivatives and complex structured credit products. Thus banks were allowed to take on all risky activities that the Great Depression had taught us could lead to problems. The lessons of history were forgotten.

The efficient market paradigm provided the intellectual backing for deregulation of financial markets in general and the banking sector in particular. At about the same time financial markets experienced a burst of innovations. Financial innovations led to the design of new financial products. These made it possible to repackage assets into different risk classes and to price these risks differently. It also allowed banks to securitize their loans, i.e. to repackage them in the form of asset backed securities (ABSs) and to sell these on the market.

This led to the belief, inspired by the optimism of the efficient market paradigm, that securitization and the development of complex financial products would lead to a better spreading of the risk over

2 The empirical evidence against the efficiency of financial markets has been building up over the last decade. For useful overviews see Shleifer (2000) and Shiller (2000).

3 See Kindleberger (2005). Chancellor (1999) also provides a vivid account of the many bubbles and crashes in the history of financial markets.

\section{Figure 1}

many more people, thereby reducing systemic risk and reducing the need to supervise and regulate financial markets. A new era of free and unencumbered progress would be set in motion.

\section{Are financial markets efficient?}

Deregulation and financial innovation promised to bring great welfare improvements: better risk spreading; lower costs of credit, benefitting firms who would invest more and benefitting millions of consumers who would have access to cheap mortgages.

The trouble is that financial markets are not efficient. We illustrate this lack of efficiency in the two dimensions that matter for the stability of the banking sector. ${ }^{2}$ First, bubbles and crashes are an endemic feature of financial markets. Second, financial markets are incapable of regulating themselves. In the end both failures brought down the new banking model that was predicated on financial markets being efficient.

\section{Bubbles and crashes are endemic in financial markets}

Nobody has written a better book on the capacity of financial markets to generate bubbles and crashes than Kindleberger in his masterful Manias, Panics and Crashes. ${ }^{3}$ Kindleberger shows how the history of capitalism is littered with episodes during which asset markets are caught by a speculative fever that pushes prices to levels unrelated to fundamental economic variables. But the lessons from history were forgotten.

Let us look at some of the bubbles and crashes that have littered financial markets during the last twen-

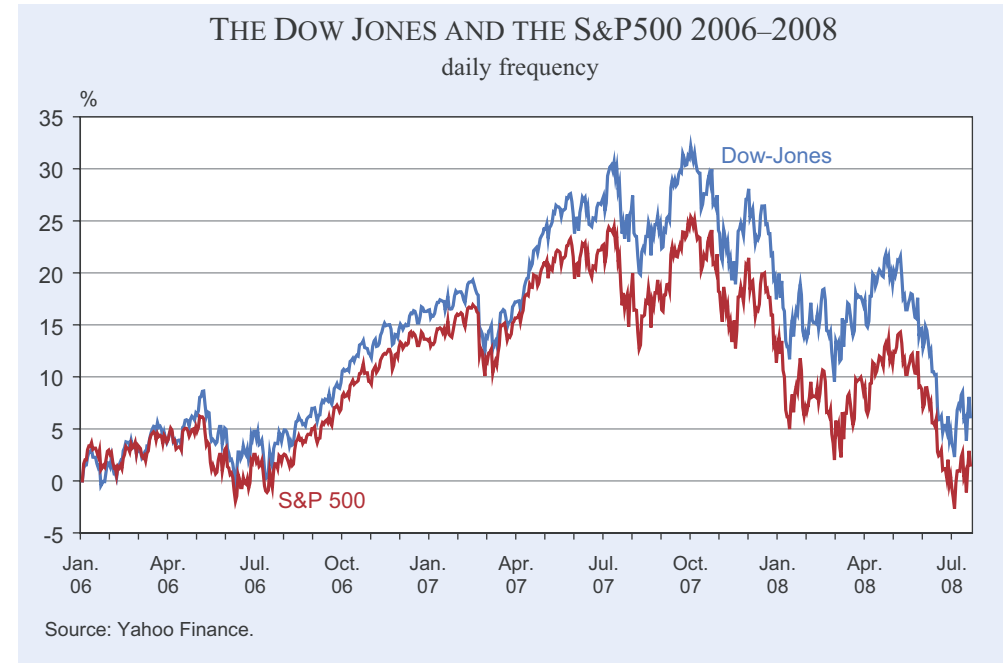


Figure 2

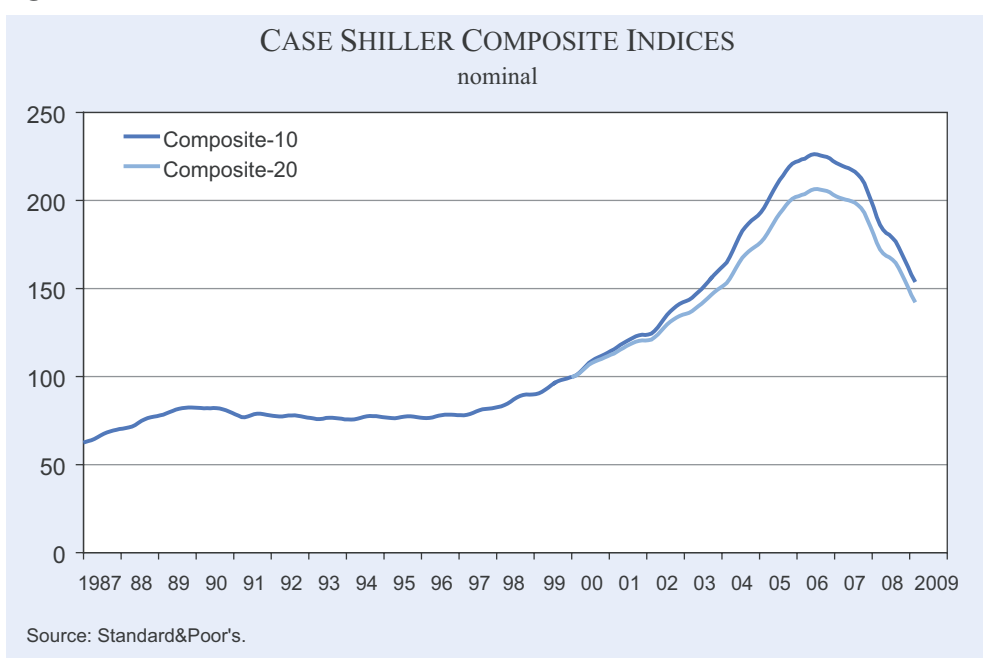

house prices in seven years time? Very little. Again the driving force was excessive optimism. Prices increased because they were expected to increase indefinitely into the future. This was also the expectation that convinced US consumers that building up mortgage debt would not create future repayment problems.

These episodes illustrate the endemic nature of bubbles and crashes in capitalist systems. They happened in the past and will continue to occur in the future. ty five years. Take the US stock market from 2006 to 2008 (see Figure 1).

What happened in the US economy between July 2006 and July 2007 to warrant an increase of 30 percent in the value of stocks? Or put differently, in July 2006 US stock market capitalization was $\$ 11.5$ trillion. One year later it was $\$ 15$ trillion. What happened to the US economy to make it possible that $\$ 3.5$ trillion was added to the value of US corporations in just one year? During the same year GDP increased by only 5 percent ( $\$ 650$ billion).

The answer is: almost nothing. Fundamentals like productivity growth increased at their normal rate. The only reasonable answer is that there was excessive optimism about the future of the US economy. Investors were caught by a wave of optimism that made them believe that the US was on a new and permanent growth path for the indefinite future. Such beliefs of future wonders can be found in almost all bubbles in history, as is made vividly clear in Kindleberger's book.

Then came the downturn with the credit crisis. In one year's time (July 2007 to July 2008) stock prices dropped by 30 percent, destroying $\$ 3.5$ trillion of value. The same amount as had been created the year before. What happened? Investors finally realized that the optimism had been excessive. The wave turned into one of excessive pessimism.

A similar story can be told about the US housing market. Figure 2 shows the Case-Shiller house price index from 2000 to 2008. During 2000-07 US house prices more than doubled. What happened to economic fundamentals in the US that warranted a doubling of
The deregulation of the banking sector that started in the 1980s fully exposed the banks to the endemic occurrence of bubbles and crashes in asset markets. Because banks were allowed to hold the full panoply of financial assets, their balance sheets became extremely sensitive to bubbles and crashes that gripped these assets. This is shown in a spectacular way in Figure 3. It illustrates how since the start of the decade the balance sheets of the major European banks exploded, reflecting the various bubbles that occurred at that time (housing bubble, stock market bubbles, commodities bubbles).

While commercial banks were increasingly involving themselves in financial markets and thus were taking over activities that were reserved to investment banks, the opposite occurred with investment banks. The latter increasingly behaved like banks, i.e., they borrowed short and lent long, thereby moving into

Figure 3

\section{European Financials' Balance Sheets Total Assets, \$ bn}

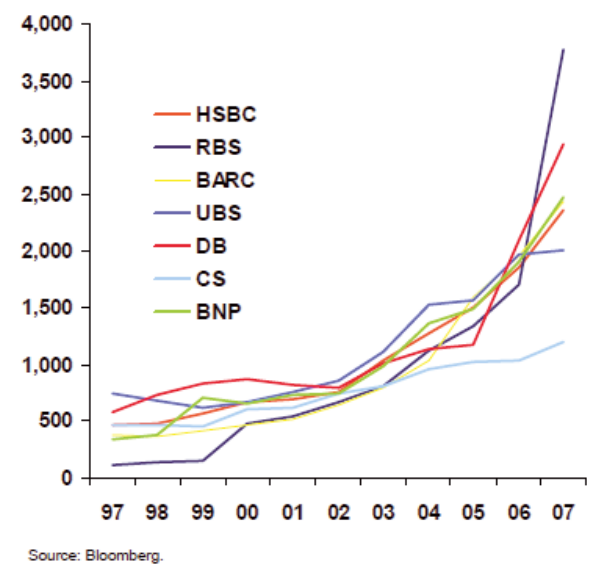


the business of credit creation. To give an example. Investment banks (e.g., Lehman Brothers) moved into the business of lending money to hedge funds and accepted stocks or other securities as collateral. They then went on and lent that collateral to others so as to make extra money. Thus, investment banks had become banks in that they were creating credit. In the process they created an unbalanced maturity structure of assets and liabilities. Their assets were long term and illiquid, while their liabilities had a very short maturity.

Thus, as a result of deregulation a double movement occurred: Commercial banks moved into investment bank territory and investment banks moved into commercial bank territory. This led to a situation in which both the commercial banks and the investment banks built up a lethal combination of credit and liquidity risks.

\section{The mirage of self-regulation of financial markets}

A centerpiece of the efficient market theory was that financial markets were capable of self-regulation, making government regulation redundant. Two mechanisms were seen as central in making self-regulation work. One was the role of rating agencies; the other was the use of mark-to-market rules.

Rating agencies would guarantee a fair and objective rating of banks and their financial products. It did not happen. The reason was that there was massive conflict of interest in the rating agencies. These both advised financial institutions on how to create new financial products and later on gave a favourable rating to the same products. Their incentives, instead of leading to the creation of sound and safe financial products, were skewed towards producing risky and unsafe products.

The other piece in the belief that markets would regulate themselves was the idea of mark-to-market. If financial institutions used mark to market rules the discipline of the market would force them to price their products correctly. Since prices always reflected fundamental values, mark-to-market rules would force financial institutions to reveal the truth about the value of their business, allowing investors to be fully informed when making investment decisions.

The trouble here again was the efficiency of markets. As we have illustrated, financial markets are regularly gripped by bubbles and crashes. In such an envi- ronment mark-to-market rules, instead of being a disciplining force, worked pro-cyclically. Thus during the bubble this rule told accountants that the massive asset price increases corresponded to real profits that should be recorded in the books. Now the reverse is happening. Mark to market rules force massive writedowns, correcting for the massive overvaluations introduced the years before, intensifying the sense of gloom and the economic downturn.

\section{Long-term solutions: a return to narrow banking}

It is time to start working on the rules for a new banking system. There are two ways to go forward. One can be called the Basle approach, the other the GlassSteagall approach.

The Basle approach accepts as a fait accompli that banks will go on performing both traditional and investment bank activities. This approach then consists in defining and implementing rules governing the risks that these banks can take. Its philosophy is that a suitable analysis of the risk profile of the banks' asset portfolios allows for calculating the required capital to be used as a buffer against future shocks in credit risk. Once these minimum capital ratios are in place, credit risk accidents can be absorbed by the existing equity, preventing banks from going broke and thereby avoiding the devilish spillovers from solvency problems into liquidity problems.

This approach has completely failed. It was first implemented in the Basle 1 accord, but was massively circumvented by banks that profited from the loopholes in the system. Basle 2 attempted to remedy this by allowing banks to use internal risk models to compute their minimum capital ratios. The underlying assumption was that scientific advances in risk analysis would make it possible to develop a reliable method of determining minimum capital ratios.

This approach to managing banks' risks does not work and will never do so, because it assumes efficiency of financial markets; an assumption that must be rejected. ${ }^{4}$ Banks that fully participate in the financial markets subject themselves to the endemic occurrence of bubbles and crashes. These lead to large

\footnotetext{
${ }^{4}$ There is a second reason why it will not work and that is conflict of interests. Supervisors should not trust complex risk models produced by bankers because the latter have a strong incentive not to reveal their true risk exposures.
} 
tail risks that with our present knowledge cannot be quantified. There is no prospect for gaining substantial knowledge about tail risks in the near future. The Basle approach must be abandoned.

This leaves only one workable approach. This is a return to the Glass-Steagall Act approach, or put differently, a return to narrow banking in which the activities banks can engage in are narrowly circumscribed. In this approach banks are excluded from investing in equities, derivatives and complex structured products. Investment in such products can only be performed by financial institutions, investment banks, which are forbidden from funding these investments by deposits (either obtained from the public of from other commercial banks).

In a nutshell a return to narrow banking could be implemented as follows. Financial institutions would be forced to choose between the status of a commercial bank and that of investment bank. Only the former would be allowed to attract deposits from the public and from other commercial banks and to transform these into a loan portfolio with a longer maturity (duration). Commercial banks would benefit from the lender of last resort facility and deposit insurance, and would be subject to the normal bank supervision and regulation. The other financial institutions that do not opt for a commercial bank status would have to ensure that the duration of their liabilities is on average at least as long as the duration of their assets. This would imply, for example, that they would not be allowed to finance their illiquid assets by short-term credit lines from commercial banks. Thus while commercial banks would be barred from engaging in activities of investment banks, the reverse would also hold, i.e., investment banks would not be allowed to borrow short and to lend long, thereby taking on liquidity risks.

Thus, we would return to a world where banking activities are tightly regulated and separated from investment banking activities. This also implies that commercial banks would no longer be allowed anymore to sell (securitize) their loan portfolio. Securitization leads to a build-up of the credit pyramid. When a bank securitizes a loan, it obtains new liquidities that can be used to grant new loans, which in turn can be used to securetize further. As a result, a credit expansion is made possible which occurs outside the supervision and control of the central bank (which, however, will be called upon to buy these assets when it becomes the lender of last resort). Put differently, securitization allows the credit multiplier to increase for any given level of the money base provided by the central bank. Credit gets out of control, endangering the whole banking system, including the central bank. It is worth stressing the latter point. The massive credit expansion made possible by securitization also endangers the balance sheet of the central bank. This is so because in times of crisis, the central bank is called upon to function as a lender of last resort. As a result, it will be faced with the need to accept as collateral securitized assets that were created by banks. Allowing banks to securitize thus means that the central bank takes on a substantial part of the risk.

The preceding argument also implies that the "originate and distribute model" that banks have increasingly used in the recent past must be abandoned. Recent proposals to save it by requiring banks to hold a fraction of the securitized assets on their balance sheets are inappropriate as they do not eliminate the risk arising from the multiplication of credit described in the previous paragraph.

A return to narrow banking will necessitate a co-operative international approach. When only one or a few countries return to narrow banking, the banks of these countries will face a competitive disadvantage. They will loose market shares to banks less tightly regulated. As a result, they will have forceful arguments to lobby domestically against the tight restrictions they face. In the end, the governments of these countries will yield and the whole process of deregulation will start again.

\section{References}

Chancellor, E. (1999), Devil Take the Hindmost: A History of Financial Speculation, Farrar, Straus and Giroux, New York.

Goodhart, C. and G. Illing (2002), eds., Financial Crises, Contagion, and the Lender of Last Resort: a Reader, Oxford University Press, Oxford.

Greenspan, A. (2007), The Age of Turbulence: Adventures in a New World, Penguin Books, London.

Kindleberger, C. (2005), Manias, Panics, and Crashes, 5th ed., Wiley, New York.

Minsky, H. (1986), Stabilizing an Unstable Economy, McGraw-Hill, New York.

Shiller, R. (2000), Irrational Exuberance, Princeton University Press, Princeton NJ.

Shleifer, A. (2000), Clarendon Lectures: Inefficient Markets, Oxford University Press, Oxford. 